\title{
Thermooxidative Behavior of Some Paint Materials in Natural Ester Based Electro-insulating Fluid
}

\author{
EDUARD MARIUS LUNGULESCUㄹ, IOSIF LINGVAY' ${ }^{1}$, LIVIA CARMEN UNGUREANU2', TRAIAN RUS ${ }^{3 *}$, ADRIANA MARIANA BORS ${ }^{4}$ \\ ${ }^{1}$ National Institute for Research and Development in Electrical Engineering INCDIE ICPE-CA Bucharest, 313 Splaiul Unirii, \\ 030138, Bucharest, Romania \\ ${ }^{2}$ National Institute for Research, Development and Testing in Electrical Engineering, 118A Decebal Blvd., 200746, Craiova, \\ Romania \\ ${ }^{3}$ Politehnica University of Bucharest, Faculty of Applied Chemistry and Materials Science, Department of Analytical Chemistry \\ and Environmental Engineering, 1-7 Polizu Str., 011061, Bucharest, Romania \\ ${ }^{4}$ ICPE SA, 313 Splaiul Unirii, 030138, Bucharest, Romania
}

\begin{abstract}
ATR / FTIR and DSC techniques have been used to evaluate the thermal stability of some ageing paint materials by heat treatment while immersion in natural ester-based electro-insulating oil. Experimental determinations have highlighted the fact that the investigated paint materials (epoxy resins) have a high oxygen affinity and thus, in closed systems (such as power transformers), they oxidize before coming into contact with the transformer oil. This behavior indicates that the paint layer (suitably chosen) applied on the inside of the transformer vat functions as an antioxidant and results in increasing the thermal stability of the oil.
\end{abstract}

Keywords: termooxidation, paints, thermal stability, insulating fluids, natural ester

The continuous and secure supply of electricity to consumers is a complex interdisciplinary issue with special economic, social and ecological implications.

Transformers are key equipment for power transport and distribution networks.

During the operation of power transformers - under the influence of thermal, electric, mechanical stress factors, etc. - afferent materials of the insulating system (usually mixed electro-insulating fluid / Kraft paper) undergoes structural changes, which leads to ageing of the insulation and lower safety in use.

Traditionally, mineral oils [1] are used as the electroinsulating fluid in the transformers, a strong biodegradable petroleum derivative [2], which, although having acceptable physical and dielectric characteristics and a relatively low cost, has a number of disadvantages such as: limited thermal stability [3-8], corrosive aggressivity due to sulfur content [8-17], reduced compatibility with the cellulose from Kraft paper - furanic products formation [18-22], relatively low flammability (below $150^{\circ} \mathrm{C}$ ) and excessive flammable gases formation [30] (high risk of explosions and devastating fires), etc. To increase thermal stability and to reduce the corrosive aggressiveness of electro-insulating oils, manufacturers often use antioxidant additives and / or corrosion inhibitors [15-17, 31].

In this context, many recent studies address the issue of replacing mineral oils with vegetable oils (triglycerides - natural esters), respectively comparing their behavior under the operating conditions from power transformers [32-41].

The durability and safety in operation of polymer materials, including the paint materials is closely related to their structural changes under the action (usually synergistic) of stress factors specific to the operating environment (temperature, ionizing and / or non-ionizing radiations, chemical stresses etc.) [42-50].

Oxidative applications may induce oxidized groups formation on the polymer chain, such as carbonyl $(C=0)$, hydroxyl (O-H), peroxides (-0-0-) or carboxyl ( $\mathrm{COOH})$ [5153].

These chemical changes are reflected in infrared spectra and can be used for qualitative and quantitative analysis of transformations induced by ageing. In electrical transformers, painting materials used for interior painting of carbon steel sheet vats, the paint films are in contact with the electro-insulating fluid (transformer oil).

Under these conditions, the chemical processes in the complex system made of paintmaterial / electro-insulating fluid / Kraft paper of insulating / copper [54-56] are largely determined by the painting material quality, dissolved oxygen in the electro insulating fluid and its quality.

It is noted that pigments (such as $\mathrm{TiO}_{2^{\prime}} \mathrm{ZnO}, \mathrm{CaCO}_{3^{\prime}}$ etc.) used in the manufacture of paints, as well as magnetic nanoparticles [57, 58] may favor electro-insulating fluid degradation processes.

In view of these considerations, the aim of the paper consist in the study the thermal-oxidative behavior of some painting materials exposed to the thermal aging at $130^{\circ} \mathrm{C}$ in an electro-insulating vegetable ester by the FTIR and DSC techniques.

\section{Experimental part \\ Materials}

For the purpose of assessing the compatibility of some paint materials with an electro-insulating fluid (vegetable oil with high oleic content, over $75 \%$, MF-UPMEE [59]), paint films with $90 \pm 10 \mu \mathrm{m}$ thickness were made by applying the paint material to a Teflon plate and detachment of the films after polymerization material.

In order to evaluate the electro-insulating fluid influence on complex processes occurring in the painting materials, type systems: electro-insulation fluid / paint film / Kraft paper / Copper, were exposed to thermal storage ageing at $130 \pm 3^{\circ} \mathrm{C}$ in a thermostatic oven, France Etuve Type XL 980 with in closed vessels, to limit oxygen access in the air.

\footnotetext{
*email: traianus@hotmail.com; Phone: +40740010485
} 
To simulate the operating conditions in the transformer, in parallel and under the same conditions $(300 \mathrm{~mL}$ oil +1 $\mathrm{dm}^{2}$ paint film from each analyzed sample as well as with added $1 \mathrm{dm}^{2}$ Kraft paper $+1 \mathrm{dm}^{2}$ copper foil) were thermally treated the following materials: $\mathbf{P M - 1 ,} \mathbf{P M - 2}$ and $\mathbf{P M - 3}$.

The copper foil used was electric used [60] and had a thickness of $30 \pm 3 \mu \mathrm{m}$. The electro-insulating paper used was of type $22 \mathrm{HCC}$, manufactured by Weidmann.

Infrared spectra were recorded with ATR (Attenuated Total Reflectance) technique. A JASCO FTIR-4200 spectrophotometer coupled with the ATR module of ASCO Pro 470-H type with diamond crystal was used for this purpose.

FTIR spectra have been corrected by ATR, $\mathrm{CO}_{2}, \mathrm{H}, \mathrm{O}$ and processed for identification of characteristic bands using the software of the equipment.

Carbonyl and hydroxyl indices values were calculated with the formula:

$$
\begin{array}{r}
C I=\frac{A_{C=0}}{A_{C H_{2}}} \\
H I=\frac{A_{O-H}}{A_{\mathrm{CH}_{2}}}
\end{array}
$$

where:

- $A_{c=0}$ is the total area of the bands corresponding to the groups, measured between $1700-1760 \mathrm{~cm}^{-1}$,

- $A$ is the band area of $\mathrm{O}-\mathrm{H}$, measured between 3300 and $3600 \mathrm{~cm}^{-1}$

- $A_{C H 2}$ is the band area of $1453 \mathrm{~cm}^{-1}$ corresponding to the stretching vibration $-\mathrm{CH}_{2}$.

Differential Scanning Calorimetry (DSC) measurements were performed using a Setaram 131 EVO (Setaram Instrumentation, France), in the following conditions: temperature range, $30-350 \mathrm{C}$; heating rate, $10 \mathrm{~K} \mathrm{~min}^{-1}$, atmosphere, air (gas flow, $50 \mathrm{~mL} \mathrm{~min}^{-1}$ ). Samples of about 2-3 $\mathrm{mg}$ were measured in aluminium pans of $30 \mu \mathrm{L}$. Specific SETARAM software has been used for data acquisition and processing. Different parameters characterizing the observed effects (peaks), such as the oxidation onset temperatures (OOT) were calculated from the DSC curves.

\section{Results and discussions}

The infrared spectroscopy and Differential Scanning Calorimetry (DSC) were used to characterize the aging effects by observing the optical absorptions corresponding to the formation of oxidized groups (e.g. carbonyl, carboxyl, hydroxyl), respectively the analysis of thermal effects occurred in the material as a result of thermosetting stability evaluation and ageing of the analysed materials.

The ATR / FTIR spectra recorded on the samples according to table 1 are shown in figurel, figure 2 and figure 3 . Table 2 shows the spectral characteristics of the investigated samples.

The obtained FTIR results show bands characteristic to epoxy resins. The different composition of the three investigated resin samples involves different crosslinking mechanisms, the positions at which the maxima of these bands appear are influenced by the intermolecular interactions caused by the epoxy-hardener resin system.

The spectra exhibit the following main bands [64-66]: wide bands of low intensity due to $\mathrm{O}-\mathrm{H}$ stretching vibration (3100-3500 $\mathrm{cm}^{-1}$ ); bands at approx. 3030-3060 $\mathrm{cm}^{-1}$ due to the aromatic C-H stretch; multiple bands in the 2830-2980 $\mathrm{cm}^{-1}$ region due to the aliphatic $\mathrm{C}-\mathrm{H}$ stretch; bands of different intensities in the $1500-1600 \mathrm{~cm}^{-1}$ region due to the $\mathrm{C}=\mathrm{C}$ stretching vibration and the $\mathrm{C}-\mathrm{O}$ stretching

Table 1

\begin{tabular}{|c|c|c|c|c|c|}
\hline $\begin{array}{c}\text { Material } \\
\text { code }\end{array}$ & $\begin{array}{c}\text { Type of painting } \\
\text { material }\end{array}$ & Composition & Solvent & Treatment applied & $\begin{array}{c}\text { Sample } \\
\text { code }\end{array}$ \\
\hline \multirow{3}{*}{$P M-1$} & \multirow{3}{*}{ AquaCover 200 [61] } & \multirow{3}{*}{$\begin{array}{c}\text { Epoxy, } \\
\text { polyamine } \\
\text { hardener }\end{array}$} & \multirow{3}{*}{ Aqua } & initial & $P M-1.1$ \\
\hline & & & & 1000 hours $\& 130^{\circ} \mathrm{C}$, in oil & $P M-1.2$ \\
\hline & & & & 1000 hours $\& 130^{\circ} \mathrm{C}$, in oil $+\mathrm{Cu}+$ paper & $P M-1.3$ \\
\hline \multirow{3}{*}{$P M-2$} & \multirow{3}{*}{ Sigmaprime 200 [62] } & \multirow{3}{*}{$\begin{array}{l}\text { two component } \\
\text { Purely epoxy }\end{array}$} & \multirow{3}{*}{$\begin{array}{c}\text { Thinner } \\
91-92\end{array}$} & initial & $P M-2.1$ \\
\hline & & & & 1000 hours $\& 130^{\circ} \mathrm{C}$, in oil & $P M-2.2$ \\
\hline & & & & 1000 hours $\& 130^{\circ} \mathrm{C}$, in oil $+\mathrm{Cu}+$ paper & $P M-2.3$ \\
\hline \multirow{3}{*}{$P M-3$} & \multirow{3}{*}{ Phenguard $930[63]$} & \multirow{3}{*}{ two component } & \multirow{3}{*}{$\begin{array}{l}\text { Thinner } \\
91-92\end{array}$} & initial & $P M-3.1$ \\
\hline & & & & 1000 hours $\& 130^{\circ} \mathrm{C}$, in oil & $P M-3.2$ \\
\hline & & & & $\begin{array}{c}1000 \text { hours \& } 130^{\circ} \mathrm{C} \text {, in } \\
\text { oil }+\mathrm{Cu}+\text { paper }\end{array}$ & $P M-3.3$ \\
\hline
\end{tabular}

INVESTIGATED PAINT MATERIALS - ANALYZED FTIR SAMPLES

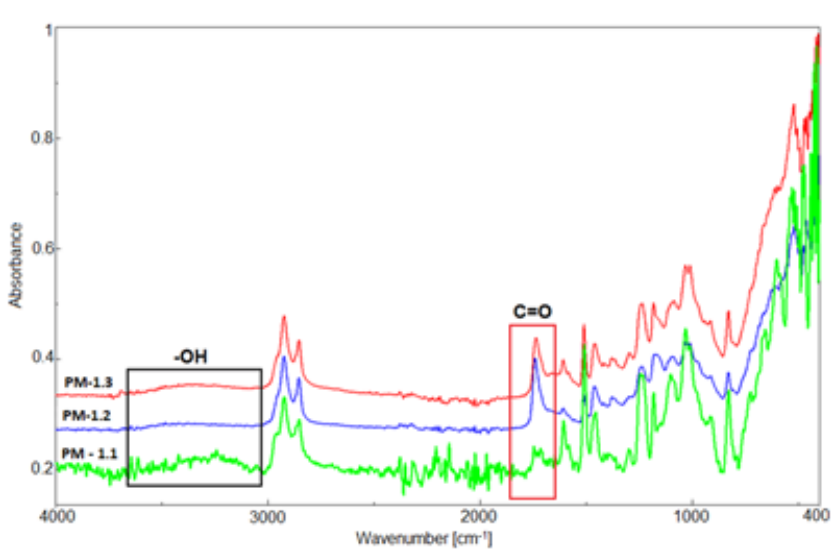

Fig. 1. FTIR spectra recorded on PM-1 samples: initially and thermally exposed

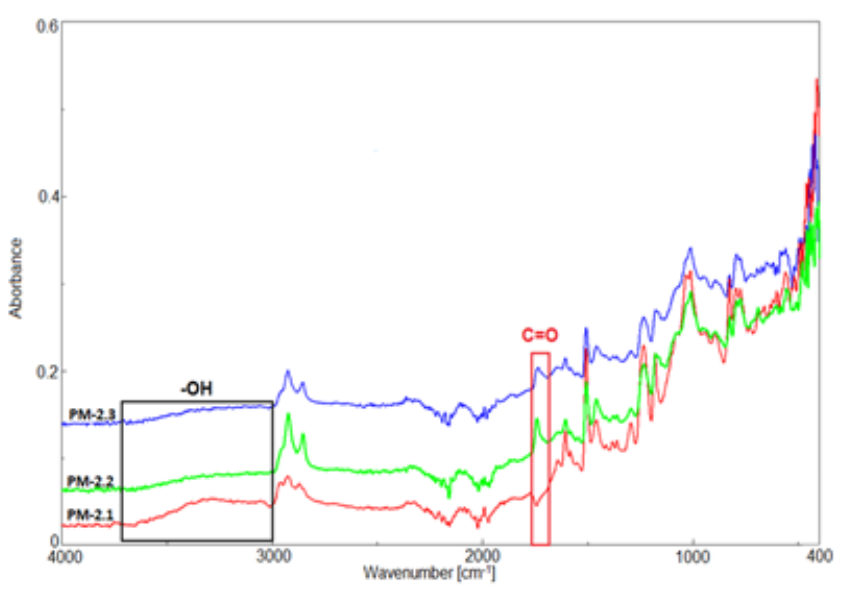

Fig. 2. FTIR spectra recorded on PM-2 samples: initially and thermally exposed 


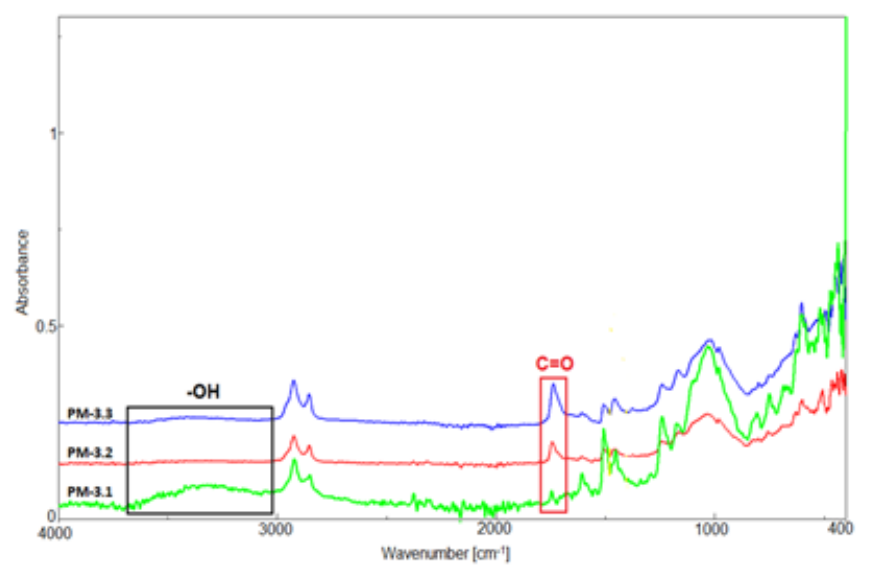

Fig. 3. FTIR spectra recorded on PM-3 samples: initially and thermally exposed

\begin{tabular}{|c|c|c|c|}
\hline \multicolumn{3}{|c|}{ Maximal absorption $\left[\mathrm{cm}^{-1}\right]$} & \multirow{2}{*}{ Spectral Attribution [64-66] } \\
\hline$P M-1$ & $P M-2$ & $P M-3$ & \\
\hline 3376 & 3384 & 3384 & $\mathrm{H}$ bonded $\mathrm{O}-\mathrm{H}$ stretch \\
\hline 3051 & 3044 & - & $\begin{array}{l}\text { C-H tension of the methylene group of the } \\
\text { epoxy ring }\end{array}$ \\
\hline 2924 & 2924 & 2921 & Asymmetric $-\mathrm{CH}$ stretch of $\mathrm{CH}_{2}$ \\
\hline 2853 & 2853 & 2852 & Symmetric $-\mathrm{CH}$ stretch of $\mathrm{CH}_{2}$ \\
\hline 1745 & 1744 & 1745 & Carbonyl stretch $(\mathrm{C}=\mathrm{O})$ \\
\hline 1645 & 1642 & 1633 & $-\mathrm{C}=\mathrm{C}-$ stretch \\
\hline 1606 & 1606 & 1607 & \multirow{2}{*}{ Aromatic $\mathrm{C}=\mathrm{C}$ stretch } \\
\hline 1582 & 1582 & 1551 & \\
\hline 1509 & 1507 & 1507 & Aromatic C-C stretch \\
\hline 1458 & 1460 & 1454 & Deformation $\mathrm{C}-\mathrm{H}$ of $\mathrm{CH}_{2}$ and $\mathrm{CH}_{3}$ \\
\hline 1376 & - & 1376 & Deformation $\mathrm{CH}_{3}$ of $\mathrm{C}-\left(\mathrm{CH}_{3}\right)_{2}$ \\
\hline 1295 & 1295 & 1292 & Bipheny1 C-C stretch or $\mathrm{CH}_{2}$ twist and rock \\
\hline 1244 & 1235 & 1241 & C-O stretch \\
\hline 1182 & 1180 & 1174 & $-\mathrm{CH}_{2}$ twist and rock \\
\hline 1100 & 1079 & 1097 & Stretching C-O-C \\
\hline 1031 & 1033 & 1031,1037 & Stretching C-O-C of ethers \\
\hline 912 & 899 & 983 & $\mathrm{C}-\mathrm{O}$ deformation of oxirane ring \\
\hline 829 & 826 & 809 & Stretching C-O-C of oxirane group \\
\hline
\end{tabular}

Table 2

SPECTRAL CHARACTERISTICS OF THE INVESTIGATED SAMPLES

\begin{tabular}{|c|c|c|c|}
\hline Sample & $\begin{array}{c}\text { carbonyl indices } \\
\mathbf{C I}(\mathbf{1})\end{array}$ & $\begin{array}{c}\text { hydroxyl } \\
\text { indices HI (2) }\end{array}$ & OOT $\left[{ }^{\circ} \mathbf{C}\right]$ \\
\hline $\boldsymbol{P M - 1 . 1}$ & 2.03 & 34.95 & 205 \\
\hline $\boldsymbol{P M}-\mathbf{1 . 2}$ & 4.50 & 16.40 & 199 \\
\hline $\boldsymbol{P M}-\mathbf{1 . 3}$ & 4.38 & 13.97 & 185 \\
\hline $\boldsymbol{P M}-\mathbf{2 . 1}$ & 1.02 & 60.48 & 205 \\
\hline $\boldsymbol{P M}-\mathbf{2 . 2}$ & 4.23 & 38.13 & 187 \\
\hline $\boldsymbol{P M}-\mathbf{2 . 3}$ & 2.49 & 41.37 & 168 \\
\hline $\boldsymbol{P M}-\mathbf{3 . 1}$ & 0.86 & 53.98 & 285 \\
\hline $\boldsymbol{P M}-\mathbf{3 . 2}$ & 2.42 & 11.32 & 241 \\
\hline $\boldsymbol{P M}-\mathbf{3 . 3}$ & 3.51 & 11.73 & 227 \\
\hline
\end{tabular}

vibrations observed at approx. $1244 \mathrm{~cm}^{-1}$ and $1027 \mathrm{~cm}^{-1}$ $[64,65]$.

In the FTIR spectra, the influence of the exposure to temperature of the oil paint samples have highlighted a significant increase (following the oxidation processes due to the dissolved oxygen in the oil $[55,56]$ of the appropriate bands carbonyl groups in the range $1700-1760 \mathrm{~cm}^{-1}$.

According to the thermoxidation mechanism [67], the primary free radicals formed in the initiation reaction participate in several subsequent reactions such as $\beta$ cleavage depolimerisation, intramolecular hydrogen transfer, and intermolecular hydrogen transfer.

Thus, the formed organic radical reacts with the polymeric substrate resulting in a peroxy radical and further to a hydroperoxide radical accompanied by a macromolecular radical, thus propagating the chain reaction process.
Thermal treatment applied to $\mathbf{P M} \mathbf{- 1}, \mathbf{P M} \mathbf{- 2}$ and $\mathbf{P M} \mathbf{- 3}$ material samples (table 1) resulted in increased concentrations of $\mathrm{C}=0$ type oxidized groups, compared to unexposed samples (table 3). Accumulation of carbonyl groups occurs through the reaction of free radicals with the oxygen. Under the experimental conditions (closed system - with limited access to oxygen from the atmosphere) the thermooxidation processes take place only with dissolved oxygen in oil.

Table 3 shows the values of carbonyl and hydroxyl indices obtained from ATR / FTIR analysis.

The analysis of the data in table 3 shows that the accumulation of carbonyl groups depends on the compositional structure of the epoxy resin system as well as on the presence of other factors such as Kraft paper and Cu foil. 


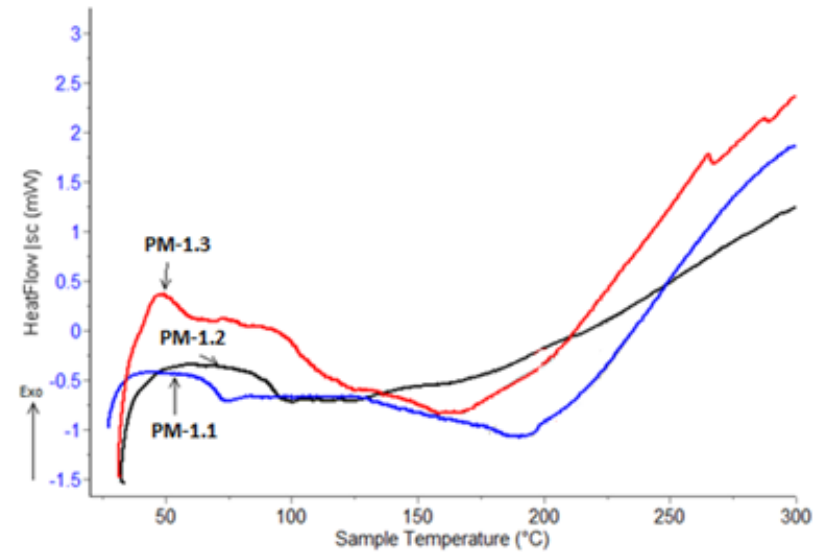

Fig. 4. DSC curves recorded on PM-1 samples: initial and thermally exposed

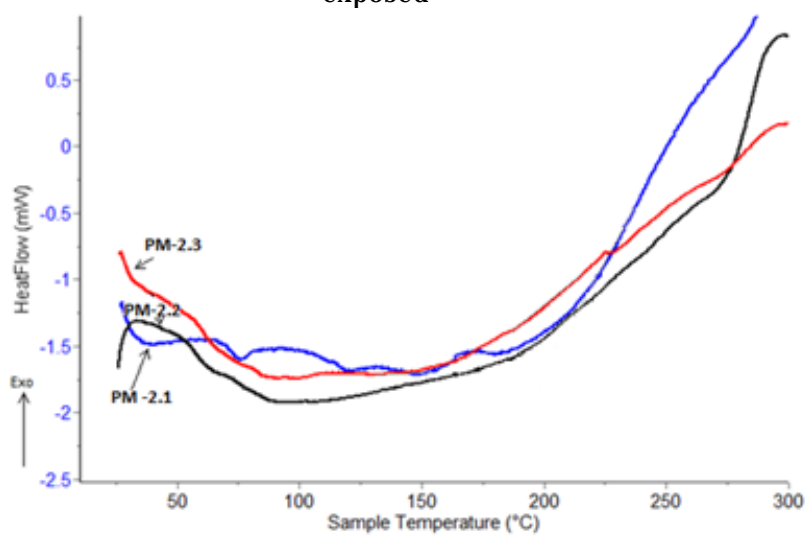

Fig. 5. DSC curves recorded on PM-2 samples: initial and thermally exposed

In the case of $\mathbf{P M} \mathbf{- 1}$ and $\mathbf{P M}-\mathbf{2}$ samples, carbonyl indices decrease slightly when the paper and the Cu foil are introduced in the medium, compared to samples exposed only in natural ester oil.

This is due to the fact that oxygen dissolved in oil also reacts with copper foil (oxidation catalyst [68]) forming $\mathrm{Cu}_{2} \mathrm{O}$ and $\mathrm{CuO}$ [14].

Thus, the oxygen available for reaction with the free radicals of the epoxy substrate becomes limited. Initial state of samples (without thermal treatment in oil) show a low concentration of $\mathrm{C}=0$ groups.

These may be associated with an oxidative degradation occurring during the process of obtaining these materials. Also, very high values of the hydroxyl indices at the initial samples compared with the aged ones can be observed.

These may be due to the presence of water in the structure of epoxy materials (they have a high water retention capacity [66]), but also of the content of intrinsic $\mathrm{OH}$ groups in the material. The results obtained by ATR / FTIR spectroscopy are confirmed by thermal stability investigations performed by DSC analysis of paint samples (figs. 4-6).

The main parameter used to describe and compare the ageing of the studied materials was the Onset Oxidation Temperature (OOT), its values being proportional to the stability of the material under exposure conditions.

In figures 4-6 the DSC curves recorded on the three types of samples are compared, and in Table 3 the OOT values obtained are shown.

The 00T values in table 3 are higher for the initial samples, decreasing to thermal exposure and are consistent with the effects of the increase in carbonyl indices observed in FTIR spectroscopy.

Oxidative stability is lower in $\mathbf{P M} \mathbf{- 1}$ and $\mathbf{P M} \mathbf{- 2}$ samples, indicating a higher oxidation susceptibility to PM-3 samples.

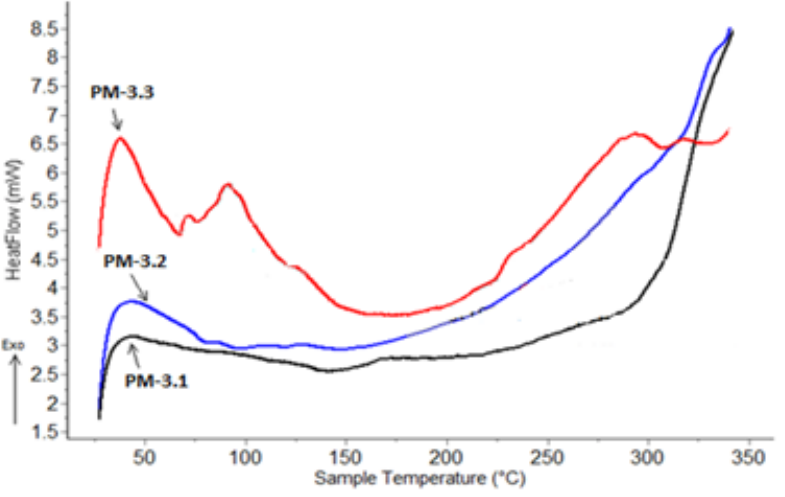

Fig. 6. DSC curves recorded on PM-3 samples: initial and thermally exposed

In the DSC curves before the oxidation peak some exothermic effects between $80-150{ }^{\circ} \mathrm{C}$ that can be attributed to decomposition of hydroperoxides [69, 70].

These effects were stronger for thermally exposed copper samples (fig. 6 - PM-3.3) than for PM-3.1 initial sample.

\section{Conclusions}

Combined ATR / FTIR and DSC techniques have been used to diagnose degradation and evaluate differences between different types of epoxy materials and changes in their chemical structure as a result of exposure to temperature under different conditions.

The exposed samples show an increase in carbonyl indices values due to free radicals with dissolved oxygen in the environment, compared to unexposed samples.

Concomitant with the increase in carbonyl indices there is a decrease in the oxidation stability of the analyzed materials, which is evidenced by the decrease of the 00T values for the aged samples.

Introducing the Kraft paper / copper system into the ageing (oil) environment leads to a decrease in carbonyl index values compared to samples without copper values.

This indicates a lower amount of oxygen for reaction with free radicals and the epoxy substrate, a portion being consumed for $\mathrm{Cu}$ oxidation, but also for oxidation of oil, copper having a catalytic role in the oxidation reaction.

In a closed environment (with restricted access to atmospheric oxygen), the high oxidation susceptibility of the epoxy materials studied can lead to the consumption of oxygen dissolved in the natural oil, acting as an antioxidant for it.

Acknowledgment: This work was financially supported by the UEFISCDI of Romania, under the scientific Programme PN II-PCCA, Contract 100/2014-UPMEE; J INR DUBNA Collaboration, Project: 04-41122-2015/2017; SMC4SERVO Project: 10PTE/2016; INTERACT- ongoing projectID: 766180/2017-2021;

\section{References}

1.ROUSE, T.O., IEEE Electrical Insulation Magazine, vol. 14 (3), 1998, p.6.

2.RADU, E., UDREA, O., MITREA, S., PATROI, D., LINGVAY, I., Electrotehnica, Electronica, Automatica (EEA), vol. 63 (4), 2015, p. 84. 3.LIAO, R., HAO, J., CHEN, G., MA, Z., YANG, L., IEEE Transactions on Dielectrics and Electrical Insulation, vol. 18 (5), 2011, p. 1626.

4.LINGVAY, I., BUDRUGEAC, P., VOINA, A., CUCOS, A., MOSCALIUC, H., Rev. Chim.(Bucharest), 67, no. 11, 2016, p. 2202.

5.CUCOS, A., BUDRUGEAC, P., LINGVAY, I., BORS, A.M., VOINA, A., Comparative TG/DTG/DTA+FTIR studies concerning the stability of some mineral and vegetable electro-insulating fluids Rev. Chim. (Bucharest), 69, 2018 in press 
6.BUDRUGEAC, P., LINGVAY, I., PICA, A., SBARCEA, B.G., Rev. Chim. (Bucharest), 68, no. 11, 2017, p. 2514.

7.DEGERATU, S., ROTARU, P., RIZESCU, S., DANOIU, S., BIZDOACA, N. G., ALBOTEANU, L. I., MANOLEA, H. O., J. Therm. Anal. Calorim., 119, no. 3, 2015, p. 1679.

8.VOINA, A., RADU, E., MITREA, S., OPRINA, G., LINGVAY, I., a ERBAN, F., PICA, A., IEEExplore, DEMISEE 2016, D0I: 10.1109/ DEMISEE.2016.7530462 p. 44.

9.LUKIC, J.M., MILOSAVLJEVIC, S.B., ORLOVIC, A.M., Indust. Eng. Chem. Research, vol. 49, 2010, p. 9600.

10.MITREA, S., OPRINA, G., RADU, E., MARINESCU, V., VOINA, A., LINGVAY, I., Rev. Chim. (Bucharest), 67, no. 9, 2016, p. 1707.

11.FACCIOTTI, M., AMARO, P.S., HOLT, A.F., BROWN, R.C.D., LEWIN P.L., PILGRIM, J.A., WILSON, G., JARMAN, P.N., Corrosion Sci., vol. 84, 2014, p. 172.

12.LINGVAY, I., OPRINA, G., MARINESCU, V., MITREA, S., Electrotehnica, Electronicã, Automaticã (EEA), vol. 64 (4), 2016, p. 5.

13.AMIMOTO, T., HOSOKAWA, N., NAGAO, E., TANIMURA, J., TOYAMA,

S., IEEE Trans. Dielectr. Electr. Insul., vol. 16, 2009, p. 1489.

14.LINGVAY, I., OPRINA, G., APOSTOL, E.S., LIPCINSKI, D., PATRU, I., MARINESCU, V., LUCHIAN, A.M., VAIREANU, D.I., Comparative studies on the behaviour of copper in various electrically insulating fluids, Rev. Chim. (Bucharest), 69, 2018 in press

15.TOYAMA, S., MIZUNO, K., KATO, F., NAGAO, E., AMIMOTO, T., HOSOKAWA, N., IEEE Trans. Dielectr. Electr. Insul., vol. 18, 2011, p. 1877.

16.DUKHI, V., BISSESSUR, A., MARTINCIGH, B.S., IEEE Transactions on Dielectrics and Electrical Insulation, vol. 22 (5), 2015, p. 2798.

17.WAN, Z.T., QIAN, H., ZHOU, S., GONG, K., HU, X., FENG, B., IEEE Trans. Dielectr. Electr. Insul., vol. 19, 2012, p. 454.

18.LINGVAY, I., UNGUREANU, L.C., OPRINA, G., STÃNOI ,V., VOINA A., PICA, A., Electrotehnica, Electronica, Automatica (EEA), vol. 65 (1), 2017, p. 62.

19.YUAN, Z., CHEN, M., LEI, H., LIN, C., IEEExplore, 2010. DoI: 10.1109/ APPEEC.2010.5449347 pp. 1-3

20.LINGVAY, I., OPRINA, G., UNGUREANU, L.C., PICA, A., STANOI, V., Rev. Chim. (Bucharest), 68, no. 12, 2017, p. 2881

21.HERMAN, H., SHENTON, M.J., STEVENS, G.C., HEYWOOD, R.J., Proceedings of the 2001 IEEE 7th International Conference on Solid Dielectrics, DOI: 10.1109/ICSD.2001.955696

22.LINGVAY, I., OPRINA, G., STANOI, V., PICA, A., UNGUREANU, L.C., SERBAN, F., Rev. Chim. (Bucharest), 68, no. 11, 2017, p. 2551.

23.SABAU J., STOCKHUYZEN R., Annual Report Conference on Electrical Insulation and Dielectric Phenomena, Victoria, BC, Canada, October 2000, vol.1, p. 264.

24.LINGVAY, I., STANOI, V., UNGUREANU, L.C., OPRINA, G., LUCHIAN, A.M., Thermochemical stability of some transformer oils - Flammable gas formation due to the thermal aging, Rev. Chim. (Bucharest), 69, 2018 in press

25.FOFANA, I., SABAU, J., BUSSIÈRES, D., ROBERTSON, E.B., Proceedings of the IEEE International Conference on Dielectric Liquids, 2008. DOI: 10.1109/ICDL.2008.4622489 pp. 1-4

26.WEESMAA, J., STERNER, M., PAHLAVANPOUR, B., BERGELD, L., NUNES, J., 18th International Conference on Dielectric Liquids, IEEExplore, DOI: 10.1109/ICDL.2014.6893096, 2014, pp. 1-8.

27.CASSERLY, E., RASCO, J.M., 18th International Conference on Dielectric Liquids, IEEExplore, DOI: 10.1109/ICDL.2014.6893100, 2014, pp. 1-4.

28.LINGVAY, I., STÃNOI, V., UNGUREANU, L.C., 'ERBAN, F., BOR', A.M., Electrotehnicã, Electronicã, Automaticã (EEA), vol. 65 (2), 2017, p. 23.

29.J OVALEKIC, M., VUKOVIC, D., TENBOHLEN, S., Proceedings of the IEEE, San Juan, Puerto Rico, 10-13 June 2012, D0I: 10.1109/ ELINSL.2012.6251517 p. 490.

30.FRIMPONG, G., PAGE, S., CARRANDER, K., CHERRY, D., ABB review, vol. 2(12), 2012, p. 49.

31.KRISHNAMOORTHY, P.R., VIJ AYAKUMARI, S., SANKARALINGAM S., IEEE Transactions on Electrical Insulation, vol. 27 (2), 1992, p. 271.
32.LINGVAY, I., BUDRUGEAC, P., UDREA, O., RADU, E., MARINESCU, M., Electrotehnicã, Electronica, Automatica (EEA), vol. 63 (1), 2015, p. 64.

33.00MMEN, T.V., IEEE Electrical Insulation Magazine, vol.1 (1), 2002, p. 6.

34.MARIN, D., STANOI, V., BADEA, I., NICOARA, T., PATRU, I., MATEI, A.T., Electrotehnica, Electronica, Automatica (EEA), vol. 65 (4), 2017, p. 101.

35.PICA, A., DUMITRU, F., Rev. Chim.(Bucharest), 67, no. 4, 2016, p.716.

36.LINGVAY, I., PATRU, I., UNGUREANU, L.C., STANOI, V., BORS, A.M., Rev. Chim. (Bucharest), 69, no. 1, 2018, p. 91.

37.SINGHA, S., ASANO, R., FRIMPONG, G., CLAIBORNE C.C., CHERRY, D., IEEE Transactions on Dielectrics and Electrical Insulation. vol. 21 (1), 2014, p. 149.

38.DUMITRAN, L.M., CIURIUC, A., NOPINGHER, P.V., Advanced Topics in Electrical Engineering, May 23-25, 2013, pp. 1-6, Bucharest, IEEExplore, 2013, DOI: 10.1109/ATEE.2013.6563459

39.ULRYCH, J., SVOBODA, M., POLANSKÝ, R., PIHERA, J., Proc. of 18th International Conference on Dielectric Liquids (ICDL), 2014, pp. 1-4, IEEExplore 2014, DOI: 10.1109/ICDL.2014.6893085

40.BERTRAND, Y., HOANG, L.C., Proc. of the 7th International Conference on Properties and Applications of Dielectric Materials; 2003; DOI: 10.1109/ICPADM.2003.1218460

41.GOMEZ, N.A., ABONIA, R., CADAVID, H., VARGAS, I.H., J. Braz. Chem. Soc. vol. 22 (12) 2011, p. 2293.

42.CIOBOTARIU, O.R., BRIA, V., GRAUR, I., VOINESCU, D.C., Rev. Chim. (Bucharest), 66, no. 11, 2015, p. 1903.

43.RUS, T., CARAMITU, A., MITREA, S., LINGVAY, I., 2016, p. 60, IEEE Xplore, 2016, DOI: 10.1109/DEMISEE.2016.7530466

44.HU, J., LI, X., GAO, J., ZHAO, Q., Progress in Organic Coatings, vol. 65, 2009, p. 504.

45.RUS, T., BORS, A.M., CARAMITU, A.R., LINGVAY, I., VAIREANU, D.I., Comparative studies on the thermal ageing of some painting materials, Mat. Plast., 58, 2018, in press

46.HUA, J., LI, X., GAO, J., ZHAO, Q., Mater. Des, vol. 30, 2009, p. 1542.

47.YANG, X.F., TALLMAN, D.E., BIERWAGEN, G.P., CROLL, S.G., ROHLIK, S., Polymer Degradation and Stability, vol. 77, 2002, p. 103. 48.BRIA, V., CIRCIUMARU, A., BIRSAN, I.G., Mat. Plast., 48, no. 2, 2011, p. 189.

49.RUS, T., LINGVAY, I., CARAMITU, A.R., BORa , A.M., VAIREANU, D.I., Mat. Plast., 54, no. 4, 2017, p. 720.

50.RUS, T., RADU, E., LINGVAY, I., LINGVAY, M., CIOBOTEA-BARBU O.C., CAMPUREANU C., BENGA, F.M., LAZAR, G.C., VAIREANU, D.I., U.P.B. Sci. Bull., Series B, vol. 79 (4), 2017, p. 167.

51.ILIE, S., SETNESCU, R., LUNGULESCU, E.M., MARINESCU, V., ILIE, D., SETNESCU, T., MARES G., Polym. Test., vol. 30, 2011, p.173.

52.STANCU, C., NOTINGHER, P.V., NOTINGHER, P., LUNGULESCU M., IEEE Trans. Dielectr. Electr. Insul. vol. 23 (2), 2016, p. 633.

53.GARDETTE, M., PERTHUE, A., GERDETTE, J.L., JANECSKA, T., FÖLDES, E., PUKANSZKY, B., THERIAS S., Polym. Degrad. Stab., vol. 98, 2013, p. 2383.

54.LINGVAY, I., UNGUREANU, L.C., STANOI, V., RUS, T., BORa , A.M., SZATMARI, I., OPRINA, G., Electrotehnica, Electronica, Automatica (EEA), vol. 65, (4), 2017, p. 117.

55.RUS, T., CARAMITU, A.R., UNGUREANU, L.C., MARINESCU, V., BORª , A.M., VAIREANU, D.I., Mat. Plast. 58, no.1, 2018, p. 28

56.LINGVAY, I., BORS, A.M., UNGUREANU, L.C., STANOI, V., RUS, T., Rev. Chim. (Bucharest), 69, no. 5, 2018, pp. 1139

57.KIRALY, J., MARTON, K., CIMBALA, R., KOLCUNOVA, I., Electronica, Electrotehnica, Automatizari (EEA), vol. 60 (1), 2012, p. 32.

58.CIMBALA, R., KIRALY, J., GERMAN-SOBEK, M., Electronica, Electrotehnicã, Automatizãri (EEA), vol. 62 (3), 2014, p. 90.

59.*** http://www.icpe-ca.ro/proiecte/proiecte-nationale/pn-2014/ uvpmee.pdf

60.*** EN 13599:2014 - Copper and copper alloys. Copper plate, sheet and strip for electrical purposes 
61.*** https://docs.td.ppgpmc.com//download/593/593/ppg-aquacover200

62.*** https://docs.td.ppgpmc.com//dow nload/428/428/sigmaprime200-series

63.*** https://docs.td.ppgpmc.com//download/423/423/phenguard-930 64.BANO, H., KHAN, M.I., KAZMI S.A., J. Chem. Soc.Pak, vol. 33 (4), 2011, p. 454

65.WELDON, D.G., Wiley \& Sons, INC., Publication, 2002.

66.GONZALES, M.G., CABANELAS, J.C., BASELGA. J., Infrared Spectroscopy -Materials science, engineering and technology, 2012, DOI:10.5772/36323
67.BOLLAND, J.L., Rev. Chem. Soc., vol. 3, 1949, p. 1.

68.HAW KINS, W.L., CHAN, M.G., LINK, G.L., Polym. Eng. Sci., vol. 11, 1971, p. 377.

69.ASTRUC, A., BARTOLOMEO, P., FAYOLLE, B., AUDOUIN, L., VERDU, J., Polym.Testing, vol. 23 (8), 2004, p. 919.

70.RICHAUD, E., FARCAS, F., FAYOLLE, B., AUDOUIN, L., VERDU, J., Polym. Testing, vol. 25 (6), 2006, p. 829.

Manuscript received: 19.03 .2018 